\title{
Impact of Business Intelligence on Technical Creativity: A Case Study on AlHekma Pharmaceutical Company
}

\author{
Hani J. Irtaimeh \\ Business Administration Dept., Faculty of Finance \& Business, \\ World Islamic for Science \& Education University \\ Abdallah Mishael Obeidat \\ Management Information Systems Department, \\ Faculty of Administrative Science and Finance, Jadara University
}

\section{Shadi. $\mathrm{H}$ abualloush}

Management Information Systems Department,

Faculty of Administrative Science and Finance, Irbid National University

Amineh. A khaddam

Management Information Systems Department,

Faculty of Administrative Science and Finance, Amman Arab University

doi: 10.19044/esj.2016.v12n28p502 URL:http://dx.doi.org/10.19044/esj.2016.v12n28p502

\begin{abstract}
Business Intelligence, through its dimensions (data warehousing, data mining, direct analytical processing), helps the members of an organization to perceive and interpret their role in the organization's creativity. For this reason, we may assume that Business Intelligence has an impact on Technical Creativity, and that matching of Business Intelligence and Technical Creativity will improve and achieve excellence in an organization. The aim of this study is to explore the impact of business intelligence dimensions (data warehousing, data mining, direct analytical processing) on Technical Creativity in AlHekma Pharmaceutical Company as a case study. For this purpose, a questionnaire was developed to collect data from the study population which consists of 50 employees. This is aimed at testing the hypotheses and achieving the objectives of the study. The most important results that the study achieved were that there was a statistically significant impact of business intelligence with its dimensions (data warehousing, data mining, and direct analytical processing) in technical creativity. The most important recommendations of the study were the necessity of organizations dependence on modern technology in order to develop their works. Thus, this is because this technology is recognized by its high accuracy on a
\end{abstract}


completion of the work, as well as deepening the concept of technical creativity which gives them a competitive advantage in the market.

Keywords: Business intelligence, data warehousing, data mining, direct technical creativity, analytical processing, AlHekma pharmaceutical company.

\subsection{Introduction}

Our current era (information era) is distinguished by its frequent change, abundance of information, and the emergence of a new and renewable knowledge. Here, the information technology plays a prominent role in this era. This was done so that organizations can adapt to the requirements of this era. However, they must keep pace with this evolution in possession of information systems that enables them to control their work. Due to the intensified competition between organizations and the challenges faced by organizations, they have resorted to the use and development of computer-based information systems, especially intelligent systems. Therefore, this enables the Organization to develop its business and its products and services, and to enter a world of competition and excellence (Alhayaly, 2009). Subsequently, the use of business intelligence systems contributes to and plays an important role in arousing and stimulating the creative faculties of organizations (Shalabi, 2009). In addition, it adds value to their business by obtaining different creative output which leads to the putting up of new products and services, and the designs of new methods of processes (Malkawi, 2007).

\subsection{Study Problem}

Despite technological development in various technical and administrative fields, organizations still experience failures in using business intelligence systems which serve to strengthen the organization's excellence and their ability to survive. This is in addition to their role in the organization's creativity which helps in the provision of new products and services. Consequently, the study's problem can be illustrated by the following questions:-

- Is there any clear perception among AlHekma pharmaceutical company on the importance of using business intelligence systems?

- Is there any significant impact to use business intelligence systems on technical creativity?

- Is there any clear perception of the organization on the concept of technical creativity?

- Is business intelligence employed in AlHekma pharmaceutical company to achieve technical creativity? 


\subsection{Study Objectives}

The study aims to:

- Identify the impact of business intelligence systems on technical creativity.

- Acknowledge the organizations importance in using business intelligence systems and their role in technical creativity.

- Accomplish empirical results which contribute to the development of the Organization's operations and make recommendations and proposals in this regard.

\subsection{Study Hypothesis}

H0 -There is no statistically significant effect of different dimensions of business intelligence on technical creativity.

\section{Sub Hypotheses}

$\mathrm{H0:1-}$ There is no statistically significant impact of data warehousing on technical creativity.

$\mathrm{H0:2}$ - There is no statistically significant impact of data mining on technical creativity.

$\mathrm{H0:3-}$ There is no statistically significant effect of online analytical processing on technical creativity.

\subsection{Theoretical Framework}

\section{1- Business Intelligence}

The term "Business Intelligence" appeared in 1958 by Hans Peter, a researcher in IBM Computer and software industry. The idea adapted by him revolved around the building of an automated system for the dissemination of information on the level of the organization. Thus, this term can be defined as a set of concepts and methods for improving business decisions using support systems based on facts (Yassin, 2012). Thus, this idea was activated by Howard Dresner who is an employee in a Gartner firm in 1989 from the onset of the term "business intelligence." Furthermore, business intelligence is known as the procedure that was aimed at the oriented-user which leads to information access. Furthermore, it involves the process of exploring, analyzing, and developing this information in a way that leads to a better understanding of how the decisions are taken (Cortel, 2012).

Researchers did not agree with the definition and interpretation of the term "business intelligence." Turban (2011) defined it as a combination of methodologies and processes, tools, and techniques that address data and turn it into information, and information into knowledge, and this accumulated experience and accumulated knowledge is turn into intelligently managed departments of strategic and tactical decisions and operations. However, Negash and Gray defined it as the process of combining data 
collection, storage, and knowledge management process with analysis tools to provide valuable and competitive information for planners and decision makers (Azizah, 2011). Loshin (2013) sees it as tools and technology operations which help to transform data into information and information into knowledge, and transfer knowledge to help the Organization strategy to plan about competitors.

Consequently, organizations are seeking new ways to improve their competitiveness or, at least, maintain competitive position. Also, they are trying to find more creative ways to attract customers by offering them new products and services as a requirement of business continuity. Therefore, this requires quick decisions and decisive action in response to the changes that are mostly unexpected. As a result, it subjects the organization to tremendous pressure from competitors. Hence, business intelligence helps to absorb the situation of the working environment (characterized by competition that has become more complex as a result of changing speed). This can be done by trying to predict the direction to be taken in future work or identify opportunities or risks that must be avoided (Rizieq, 2012). In addition, business intelligence assists in making the best decision by collecting, storing and analyzing data, and extracting information and knowledge which is beneficial to the Organization. It also provides instantaneous and accurate information of great value and great reliability data, which is available from several sources (Lloyd, 2011).

\subsection{Business Intelligence Components}

The great development in the business environment and the flexible architecture of business intelligence has made its technical components to be unlimited to a number of specific species. However, in general, when looking at business intelligence architecture, three major components can be viewed (Lloyd, 2011) which include:

\subsubsection{Data Warehouses}

In 1992, William H. Inmon introduced a comprehensive and detailed definition for data warehousing which includes several characteristics that are specific and targeted: Subject-oriented, integration, Non-volatile, and it is bound to a Time Variant (Inmon, 2003).

a) Subject - oriented

Data is placed into the data warehouse by topic where data is divided into tinny sections. Thus, every part of the Organization includes: sales, marketing, data product, and customer data. As a result, you can organize and use them to support decisions within the Organization and help to give an overview of all the activities of the Organization.

b) Integration 
The concept of integration is approaching the subject-oriented so that data warehouses and gathered data from multiple sources are made constant. It also means that data integrity gained from several different sources are always heterogeneous. Also, it is converted into data warehouse which can be displayed and which is easily accessible.

c) Non-volatile

This means that after the arrival of data into the data warehouse, users cannot amend or change it (cannot delete and add). On the contrary, the data can only be read from the database and appropriate analyses can be extracted.

d) Time Variant

Warehouse keeps historical data so that this data can help in predicting the future and understanding the situation of the organization (Gajendra, 2000).

\subsubsection{Online Analytical Processing (OLAP):}

The concept of OLAP indicates the ability to analyze large amounts of data and produce data in a variety of forms, including graphs (Samurai, 2012). Thus, it can be defined as the process of formulating and executing queries, answering user queries if the organization wished to know their sales during the period of OLAP, and provide the organization with a multidimensional information which enable it to read the past, the present, and the future of the Organization (krztof, 2007). Online analytical processing (OLAP) is considered to be an effective way to retrieve and analyze data such that it is easy to create reports for management of an organization at the right time (Scheps Swain, 2008). They organize data through the level of details. Thus, one might contain data warehousing fields for the country, region, or city for each type of sales so as to organize the information level of detail (Berson \& Smith, 2007).

\subsubsection{Data Mining}

Data mining refers to the recruitment and the use of one or more technical data analysis for extracting hidden knowledge of rules and data repositories which have been cited within the Organization. Tan (2004) introduced a comprehensive and detailed definition, i.e., data mining is the process used by the computer to discover useful information from the vast amount of data stored. Also, he explained that data mining is employed to find information or useful unknown styles. In addition, Scheps Swain (2008) states that data mining is an activity, tools, and processes used to obtain the best scientific information to support decision making.

Marakas defined it as a range of activities that is used for creating a subtle and unexpected pattern of data in the data warehouse within the 
Organization. Irrespective of the number of definitions, the concept of data mining revolves around the definition of Turban (2011). Thus, it is a process which involves the use of mathematical and statistical techniques, artificial intelligence, and machine learning to identify and extract useful information and new knowledge from data warehouses.

Data mining techniques is focused on building future predictions and in detecting behavior and trends. Therefore, it gives room for implementation and decision making at the right time in answering the right questions within a short time. Thus, questions which are difficult to answer using traditional information technology consumes more time to answer and it requires a lot of analysis procedures.

\subsection{Technical Creativity}

Before turning to the concept of technical creativity, we must clarify the concept of creativity where many concepts of creativity are defined by researchers. Thus, he defined being Creative as the process by which new products or new production methods, including all phases of creativity in the development and experimental production, marketing, and commercial production and the future, requires a broad shift to support creative system with enterprises and organizations supported by the private sector. Cooke (2001) and Shalabi (2009) define Creativity as an organization's conduct in its reliance on new methods or ideas in putting up new product or new methods, or in introducing new developments. Hamud (2010) opines that the aim of creativity is to produce a particular goods or services, or it involves the use of new methods of input that has never been used. Thus, this involves the making of certain technological changes. In addition, it entails the first use of this new technology in creative work and in a work that is creative. Peter Druker defined creativity as the restoration of the old by the new, or to make something better (Malkawi, 2007).

Authors and researchers have classified creativity in several types due to their interests and attitudes, or the nature of the Organization and its products or the creative process. However, creativity is being employed in several ways. Creativity and ingenuity or creativity means an internal and external creative and creativity of the product creation process. Hence, we can say that creativity is at the level of the Organization as a whole. Also, it can be classified into two basic types which constitute both aspects or other types of creativity (Harem, 2009). They include:

(1) Administrative Creativity: includes changes in organizational structure, design, operations of the Organization, new policies and strategies, new control systems, and others. 
(2) Technical Creativity: includes the development of new products or services, or changes in the techniques used by the Organization, changes in production methods, computerization, and others.

Technical creativity, as perceived by Shodjai (1995), is a process that requires cooperation and coordination between a number of overlapping activities in the Organization. This is aimed at adopting and using new ideas and technological advances in regular operation methods for the purpose of providing a new goods or services for the Organization, or a new or improved process design in order to satisfy the desires of customers. Thus, this helps in the achievement of the Organization's objectives in terms of survival and growth, and it make them more competitive. Consequently, Diaye (2002) explained that technical creativity refers to a series of technical and industrial steps which contributes to bringing new products into the market. William (2007) assures that technical creativity is used to discover and develop products (goods or services) or processes. Also, technical creativity involves the development of new knowledge and translating them into commercial applications.

Many researchers (Hasan, 2008; Ameri, 2002; Alrawi, 2005) have agreed that technical creativity is classified into product creativity and ingenuity of the operation.

1- Product Creativity: Includes providing new product and improving an existing product (current product).

2- Process creativity: Includes designing or using a new process and improving the existing process (the current process).

\subsection{The Importance of Technical Creativity}

The emergence and development of technical creativity is the key to market development and growth. This can be achieved through the creation of strong links between the events and the dissemination of knowledge, technical progress, and long-term growth in productivity and wealth. Therefore, technical creativity play an increasing role in manufacturing and services to generate new and improved technology and support, product alternatives to new services, and high-quality options (Turban, 2011).

Creech pointed out that the Organization should provide the conditions that help in providing an appropriate environment for the creative process through the free flow of ideas, giving employees the freedom to work, and to encourage managers of new ideas to improve the creative process in the Organization. Thus, this is in addition to providing some characteristics of technical creativity so it can be marketed "accepted" in the market, open new ports to the Organization in new markets, increase in its market share, less technical maladies in production through good designs, and work in 
enhancing the competitive advantage of the organization (Husain, 2010).

\subsection{Methodology of the Study}

Consequently, this study embraced both the descriptive level and the analytical levels. Through the descriptive study, the study sample was served and its main characteristics which would be responded to later were identified. However, this was done through the analytical approach. All the collected data was analyzed through the questionnaire given to the Study sample by using appropriate statistical methods.

\subsection{Study Model}

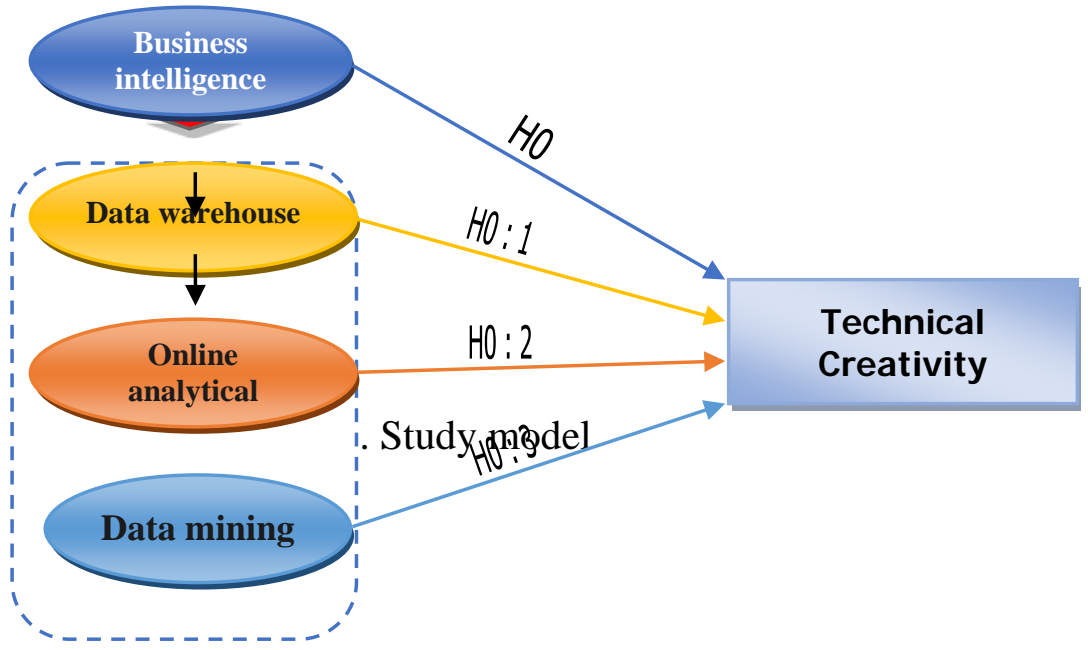

A model of the study was built on the basis of several earlier studies. The first is the independent variable which is business intelligence. Here, the researcher tested three dimension (data warehouse, online analytical process, data mining) based on the following references: Negash \& Gray, 2003; David loshin, 2013; Lloyd, 2011; and Abualoush, 2014. However, no dimensions have been taken to the independent variable. Furthermore, it was adopted as the independent variable with reference to several studies, including that of Cooke (2001) and Willam (2007).

\subsection{Study Population and Sample}

The study sample consisted of all employees of the IT Department. This is in addition to all the staff of the supply chain by AlHekma pharmaceutical companies. Thus, they consist of 50 employees. A comprehensive survey has been adopted where 50 questionnaires were distributed and 46 were retrieved. After checking that, 2 were found unfit for 
the analysis. Therefore, the questionnaires which were subject to analysis were 44 , and it constituted $90 \%$ of the study population.

\subsection{Study Tool}

For the purpose of achieving the objectives of the study, the study consists of two parts, namely: the identification Part one and Part two. The identification part 1 includes demographic variable which is based on the characteristics of the study sample according to the following personal factors such as gender, age, educational qualification, employment experience etc. Also, Part two includes 30 measures of the independent variable dimensions of business intelligence (data warehousing, data mining, direct analytical processing) and the dependent variable technical creativity.

\subsection{Instrument Validity}

The questionnaire was presented to a group of professors and specialists in the field of administrative sciences to express their opinion therein. Whereas the suggestions and recommendations received from them regarding the phrases thereof have been taken. Also, the necessary amendments have been conducted based on the paragraphs of the study. Some of the paragraphs of the study have been rewritten and reformulated.

\subsection{Instrument Reliability}

In measuring the study tool reliability (questionnaire), the reliability coefficient (Cronbach Alpha) was been used to show the extent of the internal consistency of the phrases which forms the standards which were adopted by the study. Subsequently, the results indicate that the reliability coefficient of all dimensions is not less than 0.60 . The reliability coefficient of all the paragraphs of the questionnaire was 0.918. Therefore, this means that the study tool is characterized by being stable. It is considered acceptable in the researches related to human sciences.

Table (1). Test internal consistency (Cronbach Alpha)

\begin{tabular}{|c|l|c|c|}
\hline$\#$ & \multicolumn{1}{|c|}{ Dimension } & Number of paragraphs & Cronbach alpha. \\
\hline 1. & Data warehouses & $1-5$ & 0.891 \\
\hline 2. & Data mining & $6-9$ & 0.913 \\
\hline 3. & Direct analytical processing & $10-14$ & 0.932 \\
\hline 4. & Technical creativity & $15-30$ & 0.904 \\
\hline 5. & General measure & 30 & 0.918 \\
\hline
\end{tabular}

\subsection{Characteristics of the Study Sample}

The sample contains most of the characteristics that distinguishes members of the society. Thus, the proportion of males is more than females. For male ratio (77.3\%), it can be explained that the company relies on males in its departments. With regard to the age groups, half of the age group was 
(30 years or less) followed by age group (31-40 years). Also, it explains that the Organization had replacement method. In other words, young people are recruited majorly for two reasons. One is attracting new blood to modern science, while the second is to transfer the experience from the oldest to the newest generation in preparing new leaders. Most respondents with an undergraduate degree has a percentage of $65.9 \%$, while the rest has a master's degree or a higher diploma. Subsequently, this may be due to personal reasons of the employee or that the Organization attracts top graduates. Generally, RPR respondents are distinguished through experience. Here, the proportion of those who has an experience of 5 years or more (57.8\%) corresponds to the previous lineage.

\subsection{Description of the Study Variables}

\subsection{Description of Variable Data Warehouse}

Table (2). Description of variable data warehouse

\begin{tabular}{|c|l|c|c|c|c|}
\hline$\#$ & \multicolumn{1}{|c|}{ Paragraph } & M & S.d. & Rank. & $\begin{array}{c}\text { Relative } \\
\text { importance }\end{array}$ \\
\hline 1. & $\begin{array}{l}\text { Data warehouses in the Organization has the } \\
\text { ability to store large amounts of data }\end{array}$ & 4.46 & 0.73 & 1. & High \\
\hline 2. & Data stored with high quality & 3.84 & 0.78 & 5. & High \\
\hline $\begin{array}{l}\text { Data warehouses contain information on the } \\
\text { Organization's external environment (suppliers, } \\
\text { competitors) }\end{array}$ & 4.06 & 0.83 & 2. & High \\
\hline 4. & $\begin{array}{l}\text { Data warehouses provide comprehensive } \\
\text { information to meet the needs of the beneficiary }\end{array}$ & 3.91 & 0.94 & 3. & High \\
\hline 5. & Easy access to data repositories by serving & 3.89 & 1.04 & 4. & High \\
\hline General measure & 4.03 & 0.61 & & High \\
\hline
\end{tabular}

Table (2) indicates that the mean of data warehouses was 4.03 and it has a high relative importance. Paragraph "Data warehouses in the Organization has the ability to store large amounts of data" was first with mean (4.46), standard deviation (0.73), and a high relative importance. While paragraph of high quality stored data was last with mean (3.84), standard deviation (0.78), and high relative importance too. 
7.2 Description of Variable Data Mining

Table (3). Description of variable data mining

\begin{tabular}{|c|l|c|c|c|c|}
\hline$\#$ & \multicolumn{1}{|c|}{ Paragraph } & M & S.d. & Rank. & $\begin{array}{c}\text { Relative } \\
\text { importance }\end{array}$ \\
\hline 6. & $\begin{array}{l}\text { Data mining technology helps in creating } \\
\text { models and new relationships previously } \\
\text { unknown }\end{array}$ & 4.02 & 0.70 & 3. & High \\
\hline 7. & $\begin{array}{l}\text { Contribute to Data mining technology in } \\
\text { the process of predicting the future }\end{array}$ & 4.16 & 0.61 & 1. & High \\
\hline 8. & $\begin{array}{l}\text { Data mining technology contributes to } \\
\text { predict customer behavior and trends }\end{array}$ & 4.05 & 0.71 & 2. & High \\
\hline 9. $\begin{array}{l}\text { Provide mining } \\
\text { technology Employees with information } \\
\text { contributes to creativity }\end{array}$ & 4.78 & 0.64 & 4. & High \\
\hline General measure & 4.00 & 0.49 & & High \\
\hline
\end{tabular}

Table (3) indicates that the mean of data mining was 4.00 and it has a high relative importance. Paragraph "Contribute to Data mining technology in the process of predicting the future" was first with mean (4.16), standard deviation (0.061), and high relative importance. While paragraph of "Provide the Data mining technology Employees with information contributes to creativity" was last with mean (3.78), standard deviation (0.64), and high relative importance too.

\subsection{Online Analytical Processing Variable Descriptions}

Table (4). online analytical processing variable description

\begin{tabular}{|c|l|c|c|c|c|}
\hline$\#$ & \multicolumn{1}{|c|}{ Paragraph } & M & S.d. & Rank. & $\begin{array}{c}\text { Relative } \\
\text { importance }\end{array}$ \\
\hline 10. & $\begin{array}{l}\text { Availability of Data analysis } \\
\text { systems Reports on the Organization's } \\
\text { performance for different time periods }\end{array}$ & 4.30 & 0.49 & 1. & High \\
\hline 11. & $\begin{array}{l}\text { You Data analysis systems Display } \\
\text { information in clear ways easily } \\
\text { understood }\end{array}$ & 4.21 & 0.70 & 2. & High \\
\hline 12. & $\begin{array}{l}\text { You Data analysis systems to provide the } \\
\text { user with instantaneous information } \\
\text { topical) }\end{array}$ & 4.16 & 0.63 & 3. & High \\
\hline 13. & $\begin{array}{l}\text { Provide data analysis of information } \\
\text { systems with a high degree of detail. }\end{array}$ & 3.98 & 0.83 & 5. & High \\
\hline 14. & $\begin{array}{l}\text { Availability of Data analysis } \\
\text { systems Instant information about the } \\
\text { current performance of the organization }\end{array}$ & 4.02 & 0.85 & 4. & High \\
\hline General measure & 4.23 & 0.98 & & High \\
\hline
\end{tabular}

Table (4) indicates that the mean of OLAP was 4.23 and it has a high relative importance. Paragraph "Availability of Data analysis systems Reports on the Organization's performance for different time 
periods" was first with mean (4.30), standard deviation (0.49), and high relative importance. While paragraph of "Provide data analysis of information systems with a high degree of detail” was last with mean (3.98), standard deviation (0.83), and high relative importance too.

\subsection{Description of Variable Technical Creativity}

Table (5). Description of variable technical creativity

\begin{tabular}{|c|l|c|c|c|c|}
\hline$\#$ & \multicolumn{1}{|c|}{ Paragraph } & $\mathrm{M}$ & S.d. & Rank. & $\begin{array}{c}\text { Relative } \\
\text { importance }\end{array}$ \\
\hline 15. & You introduce new products & 4.07 & 0.85 & 6. & High \\
\hline 16. & $\begin{array}{l}\text { Products that drive the organization satisfy customer } \\
\text { wishes }\end{array}$ & 3.96 & 0.77 & 9. & High \\
\hline 17. & $\begin{array}{l}\text { Manage the Organization products interest raise } \\
\text { attraction and attention }\end{array}$ & 3.82 & 0.97 & 13. & High \\
\hline 18. & $\begin{array}{l}\text { Contribute to information technology in the design of } \\
\text { new products }\end{array}$ & 3.93 & 0.87 & 11. & High \\
\hline 19 & $\begin{array}{l}\text { Organization's products are subject to continuous } \\
\text { improvement }\end{array}$ & 4.02 & 0.82 & 8. & High \\
\hline 20. & $\begin{array}{l}\text { The organization relies on clear policies to make the } \\
\text { product meets specifications }\end{array}$ & 4.23 & 0.92 & 2. & High \\
\hline 21 & $\begin{array}{l}\text { Improve organization products based on customer's } \\
\text { wishes. }\end{array}$ & 3.75 & 0.97 & 14. & High \\
\hline 22 & $\begin{array}{l}\text { Organization's products have a high degree of } \\
\text { confidence when you use them }\end{array}$ & 4.25 & 0.81 & 1. & High \\
\hline 23 & $\begin{array}{l}\text { The diversity of the organization method of producing } \\
\text { their products }\end{array}$ & 4.14 & 0.63 & 3. & High \\
\hline 24 & $\begin{array}{l}\text { Keeping pace with modern technological developments } \\
\text { organization management in product design }\end{array}$ & 4.09 & 0.68 & 4. & High \\
\hline 25 & $\begin{array}{l}\text { The organization is working on the design of new } \\
\text { processes in order to produce new products }\end{array}$ & 3.71 & 0.88 & 16. & High \\
\hline 26 & $\begin{array}{l}\text { Contributes to the Organization's staff to design new } \\
\text { processes for the production of products }\end{array}$ & 3.96 & 0.83 & 10. & High \\
\hline 27. & $\begin{array}{l}\text { Quality improvement plans are applied to production } \\
\text { processes }\end{array}$ & 4.06 & 0.75 & 7. & High \\
\hline 28 & $\begin{array}{l}\text { The organization is committed to preparing and } \\
\text { implementing accurate delivery schedules }\end{array}$ & 3.72 & 0.82 & 15. & High \\
\hline 29 & $\begin{array}{l}\text { Good product delivery speed is compared with } \\
\text { competitors }\end{array}$ & 4.07 & 0.69 & 5. & High \\
\hline 30 & $\begin{array}{l}\text { The Organization's production process is exposed to } \\
\text { continuous improvement }\end{array}$ & 3.86 & 0.82 & 12. & High \\
\hline General measure & 3.98 & 0.52 & & High \\
\hline
\end{tabular}

Table (5) indicates that the mean of technical creativity was 3,98 and it has a high relative importance. Paragraph "Organization's products have a high degree of confidence when you use" was first with mean $(4,25)$, standard deviation (0.81), and high relative importance. While paragraph of 
"The organization is working on the design of new processes in order to produce new products” was last with mean (3.71), standard deviation (0.82), and high relative importance too.

\section{Hypotheses Testing}

The study hypotheses were tested using simple and multiple linear regressions. The main hypotheses are

H0: No statistically significant impact of business intelligence (DW, OLAP, DM) on technical creativity.

Table No (6). The results of multiple regression analysis indicate that business intelligence (DW, OLAP, DM) affects technical creativity

\begin{tabular}{|c|c|c|c|c|}
\hline Information system & $(\mathrm{B})$ & $(\beta)$ & $\mathrm{T}$ & $\mathrm{p}$-value \\
\hline DW & 0.233 & 0.154 & 3.316 & 0.000 \\
\hline OLAP & 0.262 & 0.256 & 3.765 & 0.000 \\
\hline DM & 0.233 & 0.377 & 3.145 & 0.000 \\
\hline R & \multicolumn{5}{|c|}{0.521} \\
\hline R2 & \multicolumn{5}{|c|}{0.432 .156} \\
\hline F & \multicolumn{5}{|c|}{0.000} \\
\hline P-value & \multicolumn{5}{|c|}{} \\
\hline
\end{tabular}

Table No. (6) shows us the results of multiple regression analysis to the impact of business intelligence systems with its three dimensions as an independent variable in the technical creativity. Table No. (2) shows that the value of the coefficient of determination is R2 $=0.432$. This explains a percentage of $43.2 \%$ of the impact of business intelligence on technical creativity. The coefficient correlation has reached $\mathrm{R}=0.521$, while the value is $\mathrm{F}=71.156$. The potential value is given as $\mathrm{P}$-value $=0.000$; thus, it is lower than the approved significance level (0.05). Accordingly, we reject the null hypothesis $\mathrm{H} 0$, which states that there is no statistically significant impact of business intelligence on technical creativity. Also, we accept the alternative hypothesis, which states the presence of a statistically significant impact of business intelligence on technical creativity.

Table No. (6) also shows the impact of each dimension of business intelligence on technical creativity. Here, the results indicated that the dimensions that have a statistical significance and impact on technical creativity is DW which reached $\beta=0.154$. This is a statistical significance, because the value is given as $\mathrm{t}=3.316, \mathrm{P} \leq$ 0.05 . Thus, the OLAP value has reached $(\beta 0.256)$. This is a statistical significance because the value is given as $\mathrm{t}=3.765, \mathrm{P} \leq$ 0.05 . The DM value has reached $\beta=0.377$. Therefore, this is a statistical significance because the value is given as $\mathrm{t}=3.145, \mathrm{P} \leq$ 0.05 . 


\section{Sub-Hypotheses}

To test the sub hypotheses, simple linear regression analysis were used to determine the impact of the independent variable on technical creativity. Therefore, the results were given as follows:

HO:1- No statistically significant impact of data warehouses in technical creativity.

Table (7). The results of simple regression analysis indicate that the data warehouses affects the technical creativity

\begin{tabular}{|c|c|c|c|c|c|c|c|c|c|c|}
\hline \multirow[b]{2}{*}{$\begin{array}{c}\text { Dependent } \\
\text { variable }\end{array}$} & \multirow[b]{2}{*}{$\mathrm{R}$} & \multirow[b]{2}{*}{$\mathrm{R}^{2}$} & \multirow[b]{2}{*}{$\begin{array}{c}\mathrm{F} \\
\text { Calculated }\end{array}$} & \multirow{2}{*}{$\begin{array}{c}\text { DF } \\
\text { Degrees } \\
\text { of } \\
\text { freedom }\end{array}$} & \multirow[b]{2}{*}{ Sig*** } & \multicolumn{5}{|c|}{ Regression coefficient } \\
\hline & & & & & & $\begin{array}{c}\text { The } \\
\text { statement }\end{array}$ & B & $\begin{array}{l}\text { Standard } \\
\text { error }\end{array}$ & $\begin{array}{c}\mathrm{T} \\
\text { Calculated }\end{array}$ & Sig** \\
\hline \multirow{2}{*}{$\begin{array}{l}\text { Technical } \\
\text { creativity }\end{array}$} & \multirow[b]{2}{*}{0.683} & \multirow[b]{2}{*}{0.466} & \multirow[b]{2}{*}{36.63} & 1. & \multirow[b]{2}{*}{0.000} & \multirow{2}{*}{$\begin{array}{c}\text { Data } \\
\text { warehouses }\end{array}$} & \multirow[b]{2}{*}{0.586} & \multirow[b]{2}{*}{0.079} & \multirow[b]{2}{*}{6.052} & \multirow[b]{2}{*}{0.000} \\
\hline & & & & 42 & & & & & & \\
\hline
\end{tabular}

* Statistically significant impact ( $\alpha \leq 0.05$ )

Table (7) results show simple regression model of technical creativity of the dependent variable on independent variable data warehouse of moral statistical significance 0.05 . So the value of Calculated (F) is equal to 36.63 with level indicator (Sig $=0.000$ ). Also, the value of the coefficient correlation (0.683) is evidence of a positive relationship between variables. As the coefficient of determination was 0.466 , the independent variable explains $46.6 \%$ Changes in the dependent variable. This, however, is in addition to a degree value $\beta$ amounted (0.586), representing the total effect of variable data warehousing on technical creativity and is statistically significant. Therefore, the value of calculated (t) was 6.052 at a statistical significance of 0.05 , Therefore, this shows that there is a statistically significant impact of data warehouses on technical creativity.

HO:2- No statistically significant impact of data mining in technical creativity

Table (8). The results of simple regression analysis indicate that Data mining affects technical creativity

\begin{tabular}{|c|c|c|c|c|c|c|c|c|c|c|}
\hline \multirow[b]{2}{*}{$\begin{array}{c}\text { Dependent } \\
\text { variable }\end{array}$} & \multirow[b]{2}{*}{$\mathrm{R}$} & \multirow[b]{2}{*}{$\mathrm{R}^{2}$} & \multirow[b]{2}{*}{$\begin{array}{c}\mathrm{F} \\
\text { Calculated }\end{array}$} & \multirow[b]{2}{*}{$\begin{array}{c}\text { DF } \\
\text { Degrees } \\
\text { of } \\
\text { freedom }\end{array}$} & \multirow[b]{2}{*}{$\begin{array}{c}\text { Sig** } \\
\text { Level of } \\
\text { The } \\
\text { indication }\end{array}$} & \multicolumn{5}{|c|}{ Regression coefficient } \\
\hline & & & & & & $\begin{array}{c}\text { The } \\
\text { statement }\end{array}$ & B & $\begin{array}{l}\text { Standard } \\
\text { error }\end{array}$ & $\begin{array}{c}\mathrm{T} \\
\text { Calculated }\end{array}$ & $\begin{array}{c}\text { Sig** } \\
\text { Level of } \\
\text { The } \\
\text { indication }\end{array}$ \\
\hline \multirow{3}{*}{$\begin{array}{l}\text { Technical } \\
\text { creativity }\end{array}$} & \multirow{3}{*}{0.389} & \multirow{3}{*}{0.152} & \multirow{3}{*}{7.502} & 1. & \multirow{3}{*}{0.009} & \multirow{3}{*}{$\begin{array}{l}\text { Data } \\
\text { mining }\end{array}$} & \multirow{3}{*}{0.413} & \multirow{3}{*}{0.151} & \multirow{3}{*}{2.739} & \multirow{3}{*}{0.009} \\
\hline & & & & 42 & & & & & & \\
\hline & & & & 43 & & & & & & \\
\hline
\end{tabular}

* Statistically significant impact $(\alpha \leq 0.05)$

Table (8) results show a simple regression model of technical creativity of the dependent variable on independent variable data mining of 
moral statistical significance 0.05 . So, the value of Calculated $(F)$ is equal to 7.502 with level indicator (Sig $=0.009$ ). Also, the value of the coefficient correlation (0.389) is evidence of a positive relationship between variables. As the coefficient of determination was 0.152 , the independent variable explains $(15.2 \%)$ changes in the dependent variable. This, however, is in addition to a degree value $\beta$ amounted (0.413), representing the total effect of variable data warehousing on technical creativity and is statistically significant. Therefore, the value of calculated (t) was 2.739 at a statistical significance of 0.05 . Therefore, this shows that there is a statistically significant effect for data mining in technical creativity.

HO:3- No statistically significant impact of OLAP in technical creativity.

Table (9). The results of simple regression analysis indicate that the OLAP affects the technical creativity

\begin{tabular}{|c|c|c|c|c|c|c|c|c|c|c|}
\hline \multirow[b]{2}{*}{$\begin{array}{c}\text { Dependent } \\
\text { variable }\end{array}$} & \multirow[b]{2}{*}{$\mathrm{R}$} & \multirow[b]{2}{*}{$\mathrm{R}^{2}$} & \multirow[b]{2}{*}{$\mathrm{F}$} & \multirow[b]{2}{*}{ DF } & \multirow[b]{2}{*}{$\begin{array}{l}\text { Sig** } \\
*\end{array}$} & \multicolumn{5}{|c|}{ Regression coefficient } \\
\hline & & & & & & $\begin{array}{c}\text { The } \\
\text { stateme } \\
\text { nt }\end{array}$ & $\beta$ & $\begin{array}{l}\text { Stand } \\
\text { ard } \\
\text { error }\end{array}$ & $\begin{array}{c}\mathrm{T} \\
\text { Calcu } \\
\text { lated }\end{array}$ & $\begin{array}{l}\text { Sig* } \\
* *\end{array}$ \\
\hline \multirow[b]{3}{*}{$\begin{array}{l}\text { Technical } \\
\text { creativity }\end{array}$} & \multirow[b]{3}{*}{0.840} & \multirow[b]{3}{*}{0.706} & \multirow[b]{3}{*}{101.07} & 1. & \multirow[b]{3}{*}{0.000} & \multirow{3}{*}{$\begin{array}{c}\text { online } \\
\text { analytic } \\
\text { al } \\
\text { processi } \\
\text { ng } \\
\text { Olap }\end{array}$} & \multirow{3}{*}{$\begin{array}{l}0 . \\
7 \\
3 \\
8\end{array}$} & \multirow[b]{3}{*}{0.073} & \multirow[b]{3}{*}{$\begin{array}{c}10.05 \\
3\end{array}$} & \multirow[b]{3}{*}{0.000} \\
\hline & & & & 42 & & & & & & \\
\hline & & & & 43 & & & & & & \\
\hline
\end{tabular}

* Statistically significant impact $(\alpha \leq 0.05)$

Table (9) results show a simple regression model of technical creativity of the dependent variable on independent variable OLAP of moral statistical significance 0.05 . So, the value of Calculated $(\mathrm{F})$ is equal to 101.07 with level indicator $(\mathrm{Sig}=0.000)$. The value of the coefficient correlation (0.840) is evidence of a positive relationship between variables. As the coefficient of determination was 0.706, the independent variable explains (70.6\%) changes in the dependent variable. This, however, is in addition to a degree value $\beta$ amounted (0.0738), representing the total effect of variable OLAP on technical creativity and is statistically significant. Therefore, the value of calculated (t) was 10.053 at a statistical significance of 0.05 . Therefore, this shows that there is a statistically significant impact of OLAP on technical creativity.

\subsection{Conclusion \& Recommendations}

The results of the study showed a statistically significant effect for business intelligence (data warehousing, data mining, online analytical processing) on technical creativity; a statistically significant effect of data warehouses on technical creativity; a statistically significant effect for data 
mining on technical creativity, where this was far less influenced among business intelligence dimensions in technical creativity; a statistically significant effect of online analytical processing (OLAP) on technical creativity, where this has a far stronger effect among business intelligence dimensions in technical creativity; and that modern technology is a key reason for the development of strong organizations and competition to create new products and services.

AlHekma pharmaceutical company should give greater importance to data mining technique. This is because this technique helps to predict the new products and services. AlHekma pharmaceutical company should continue in giving interests to online analytical processing technology as it is a tool that offers an advanced analysis of data structure and decision taking. AlHekma pharmaceutical company should develop and update data warehouses as they are data base which stores large amounts of data (historical data on all company activities). Subsequently, organizations should rely on modern technology in developing its works as it is distinguished by its high accuracy in accomplishing the works. Organizations must keep pace with the rapid development in information technology. Organization should adapt the concept of technical creativity which gives her competition in the market. Also, technical creativity does not only come from the thoughts of individuals and experts working with the Organization, but modern technology has contributed significantly in helping organizations to create new products and processes.

\section{References:}

1. Ajlan Hassan Hussein (2008). Strategies of knowledge management in business organizations, ethra for publishing, Amman, Jordan.

2. Al hamame Alaa Hussein (2008). Data Mining, Ethra’ for publishing and distribution. Amman, Jordan.

3. Alhayaly, Ahmed Moyad, \& Al Murad, Bin Yunus (2009). Management Information System success indicators and their role in creativity and excellence: an exploratory study in Government and private banks in the city of Mosul, "paper presented at the third Scientific Conference of the Faculty of Economics and Administrative Sciences, Department of business organizations: contemporary global challenges", 27-29/4/2009.

4. AlRawi, Safwan Yassin (2005). The effect of some environmental factors on technical creativity : an exploratory study on the selection of industrial firms in the province of Nineveh, unpublished thesis, College of management and economics, University of Mosul. 
5. Amri, Salih Mahdi Muhsin (2002). Technological Creative: a general framework, $2^{\text {nd }}$ annual scientific conference, Faculty of Economics and Administrative Sciences, University of AlZytunah, Amman, Jordan.

6. ANI, Mezher, Jawad, Shawqy, \& Hijaziv Haitham (2012). Business Intelligence and Information technology, Dar AlSafa’ Publishing, Amman, Jordan.

7. Azizah Ahmad (2011). Business Intelligence for Sustainable Competitive Advantage: The Case of Telecommunications Companies in Malaysia, thesis is presented for the Degree of Doctor of Philosophy Of Curtin University of Technology.

8. Berson Alex \& Smith Stephen (2007). Data warehousing, Data Mining\& OLAP. USA, McGraw - Hill.

9. CiosKrzstof j. PedryczWitold \& Roman Swiniarski (2007). Data Mining, A knowledge Discovery Approach , New York ,Springer .

10. Cooke Philip (2001). Regional Creative Systems, Clusters, and the Knowledge Economy, Industrial and Corporate change, Vol 10 No 4.Center for Advanced Studies, University of Wales, England.

11. Diaye Anthurimane, N (2002). Second International Forum on Creativity and Invention: A Better Future for Humanity in 21 Century "WWW.wipo.org/creative /en/meetings/2002/bei/pdf/wipo-inv-bei02-21-pdf-Similar Page .

12. Hammoud \& khudair kathem (2010). knowledge Management, Dar AlSafa’ Publishing, Amman, Jordan.

13. Han, jiawei \& Kamber Micheline (2006). Data Mining Concept and Techniques. Morgan Kaufmann publisher, USA.

14. Hareem, Hussain (2009). Organizational behavior: behavior of individuals and groups in organizations. Dar al-Hamed for publishing and distribution, Amman, Jordan.

15. Hussain, Mohammad (2010). "Technical creativity client satisfaction (guest)", Journal of business and economics, 18.

16. Inmon, w. h. (2003). Building Data Warehouse. , Wiley Computer Publishing, USA.

17. Kortell Fred (2012). Business intelligence and marketing information systems, 11 th annual scientific conference of business intelligence and knowledge-based economy of Jordan Zitouna University Faculty of Economics and Administrative information Amman, Jordan.

18. Lloyd John, (2011), "Identifying Key Components of Business Intelligence Systems and Their Role in Managerial Decision making", Master of Applied Information Management Program, University of Oregon. 
19. Loshin David (2013), Business Intelligence The Savvey Managers Guide, Elsevier Morgan Kaufmann publisher, USA.

20. Malkawi Nathem Mahmoud Mohamed (2007): "information and knowledge systems and their impact on creative: a study of the commercial banks of Jordan", unpublished Master thesis, Faculty of Economics, University of Damascus.

21. Rezzig Kamal (2012). The importance of business intelligence in the development and improvement of the performance of small and medium enterprises Algerian,11 th Annual Scientific Conference atheist ten: Business Intelligence and Knowledge Economy Jordanian Zitouna University Faculty of Economics and Administrative Sciences, Amman, Jordan

22. Scheps Swain (2008). Business Intelligence, Indiana, Wiley Publisher ,Inc, USA.

23. Shalabi, Firas \& Bani Hamdan, Khaled, (2009). The impact of information technology on organizational creativity

24. Sharma Gajendra ( 2008). Data Mining, Data warehousing and OLAP, Publishers of Engineering and computer Books, New Delhi, India.

25. Shodjai Foad (1995) "systems of creative", Centre for Policy research on science and technology. Canada

26. Solomon Negash \& Paul Gray (2003). Business Intelligence, Americas Conference on Information Systems (AMCIS) page 31893199.

27. Stevenson, William, J. (2007), "Production \& Operations Management".8th ed, Von Hoffmann Press.

28. Tan, pang-ning , Michael, Steinbach , \& Vipin, Kumar, Introduction to Data Mining, Addison Wesly, USA.

29. Turban, Efram and others (2011). "Information Technology For Management: Making connection for strategic Advantage" $2^{\text {nd }}$.ed ,: john wiley\& sons, U.S.A. 